\title{
Integrated Socio-Spatial Analysis of Soviet Era Modernist Urbanization and Its Consequences in Lithuanian Cities: Methodological Outline
}

\author{
Kęstutis Zaleckis, Kaunas University of Technology \\ Indrė Gražulevičiūtè-Vileniškè, Kaunas University of Technology \\ Jurga Vitkuvienè, Kaunas University of Technology \\ Brigita Tranavičiūte, Kaunas University of Technology \\ Huriye Armağan Doğan, Kaunas University of Technology \\ Tomas Grunskis, Vilnius Academy of Arts \\ Jolita Sinkienè, Kaunas University of Technology
}

\begin{abstract}
The massive modernist urbanization of the Soviet era in Lithuania had brought new urban lifestyle models, caused the expansion of builtup areas and affected previously organically developing urban structures. Hence, its analysis and understanding are essential for further sustainable urban development. The research presents an outline of methodology for complex analysis and evaluation of modernization of Lithuanian cities during the Soviet era and its influence on Lithuanian past and present urban development as a socio-spatial phenomenon.
\end{abstract}

Keywords - Content analysis, integrated socio-spatial analysis, Lithuania, modernist urbanization of Soviet era, multi-modal network model, network analysis, sociotop map.

\section{INTRODUCTION}

\section{A. Relevance of Research}

The paradigm of sustainable development, contemporary smart technologies that are changing the ways of interaction with urban environment, social changes after the restoration of Lithuania's independence, and the new regularities of economic life affecting the interaction of urban population and developers, demographic challenges, and the new urban development models coming from the global context, determine the inevitable ongoing transformations in Lithuanian cities. In order to avoid uncontrolled developments and unexpected qualitative changes of urban character researchers, professionals and the society must comprehend and understand these ongoing changes and the regularities of functioning of urban structures, which are both rooted in the past and determined by these changes. Consequently, it is crucial to understand and to analyse the past changes of Lithuanian cities and the patterns of functioning of urban structures determined by them using advanced methods.

The period between 1960 and 1990 of the Soviet modernist urbanization is of unquestionable importance in this regard, as it has radically changed urban territories, lifestyles, and imposed new and different models of urban planning for that time. Moreover, these models are still viable in Lithuanian urbanism even after the restoration of independence, and are frequently applied despite different social, economic, and cultural context and without any scientific evaluation of their suitability for the present day. Such situation requires complex analysis and evaluation of changes of social-spatial genotype of the large Lithuanian cities determined by the modernist urbanization of the Soviet era and specific methodology is necessary for this research. Without such analysis it is impossible to understand the development of Lithuanian cities, the peculiarities of their functioning and to solve the problems of their rehabilitation, improvement of quality of life, etc.

\section{B. Literature Review}

The analysis of modernist urbanism of the Soviet era was initiated by the senior generation of researchers. A certain comprehensive view of the phenomenon was presented by A. Miškinis [1]. Individual architectural and urban complexes of the Soviet era, especially those developed in historic urban setting, were analysed by J. Minkevičius [2] and other researchers of this generation. These analyses were based on classical methodologies of art criticism concentrating mainly on the objects with higher architectural values and focusing on the issues of architectural-urban composition. The new generation researchers working in the field of architectural history and devoting some attention to urbanism, including V. Petrulis, M. Drèmaitè, J. Tutlytė [3]-[5], ground their research on socio-historical and art criticism approaches. Researchers with architectural education working in the field of art criticism have analysed the peculiarities of development and changes of individual urban settlements and particular urban spaces that had emerged during the Soviet era [6], [7]. S. Mozūriūnaite [8], [9] has analysed the functional mutations of Lithuanian cities, for example those that had occurred in the historical urban fabric of Vilnius during the Soviet period. However, no mathematical procedures were used in these researches. K. Zaleckis and I. Matijošaitienè [10]-[12] have analysed modernist urban fabric and the transformations of historic urban centres during the Soviet era using space syntax approach. The existing body or knowledge demonstrates the maturity of Lithuanian re- 
search community to approach the Soviet era modernist urbanism in a complex way, however, such analysis are still lacking. The research of similar urban structures carried out abroad are much wider and more complex and encompass different approaches and studies ranging from the analysis of theoretical urbanization models created by Le Corbusier [13] to applied research of individual urban areas [14] and employ different tools including networks and mathematical modelling [15]. However, even in these cases the analyses are usually focused on the modernist built fabric without seeing their wider influence on the changes of genotypes of other urban areas.

The aim of research is to develop and present the outline of methodology based on the interdisciplinary theory of networks and mathematical network models for complex analysis and evaluation of Soviet era modernization of Lithuanian cities and its influence on the past and present Lithuanian urban development as a socio-spatial phenomenon. This research is part of the project funded by the Research Council of Lithuania entitled "Complex Analysis of Modernization of Lithuanian Cities in 1960-1990 and its Consequences for Lithuanian Urbanism as a Socio-spatial Phenomenon" aimed at the assessment of influence of the Soviet modernist urbanism on the functioning of large Lithuanian cities in the past and present perspectives.

\section{Methods}

The methodology of the research includes the selection and justification of basic research methods and proposals for their integration. The main steps of the research are:

1. Identification of the potential case study areas in the territory of Lithuania for the future testing and application of the methodology.

2. Selection and grounding of main methods and tools.

3. Description of data necessary for research and its potential sources.

4. Description of the possible integration of research results obtained using the above-mentioned methodologies.

The envisioned result of this stage of the research is graphical framework of the proposed methodology.

\section{Results}

\section{A. Case Study Areas}

Three largest Lithuanian cities, which had undergone massive Soviet era urbanism interventions - capital city Vilnius (area 401 sq. km, population 542 664), the second largest city and the inter-war era temporary capital city Kaunas (area 157 sq. km, population 292 677), and port city Klaipeda (area 110 sq. km, population 154275 ) - were selected to develop and test the methodology. In the process of methodology development and its calibration, the main attention was devoted to Kaunas as a particular example of combination and interaction of various types of urban structures. Kaunas served as a field laboratory for the investiga- tion; further application of the methodology to the cities of Vilnius and Klaipeda is envisioned as the future research directions.

\section{B. Methods and Tools}

The analysis of Soviet era modernist urbanization and its present influences using interdisciplinary theory of networks and mathematical network models as the main methodological tools is undoubtedly relevant as it was demonstrated by the literature review. GIS databases, complex network models and the analysis of the content of the databases using sociological tools would allow to make a qualitative and quantitative leap in the research of modernist urbanism of Lithuania in the Soviet era. The research approach is based on the theory of city as a network [16] and uses mathematical graph model, which is commonly applied in the space syntax research, analysing social, transport networks, etc. This provides the interdisciplinary and systemic background for the research and for the selection of complementary methods. The methodological framework includes:

1. Spatial analysis methods:

- GIS and GIS database development for the spatial analysis of collected historical documents;

- development of urban spatial structure network models of selected Lithuanian cities using graph analysis and space syntax analysis;

- development of multi-modal network models for the selected cities considering the separation of traffic flows characteristic to the modernist urbanism, which would allow determining more precisely the regularities of functioning of public spaces.

2. Sociological analysis methods:

- collection and analysis of documents and archival data regarding the use of public spaces before and after the Soviet urban modernization using content analysis approach;

- $\quad$ sociological survey using questionnaires and checklists of the selected characteristic modernist urban spaces developed during the Soviet era in order to fill the data gaps highlighted by the content analysis.

3. Socio-spatial analysis methods:

- development of the sociotop map [17] for the selected characteristic modernist urban spaces developed during the Soviet era using sociological survey data.

\section{Research Data}

The data necessary for the research include:

- $\quad$ spatial urban data: maps, plans, data regarding pedestrian paths, public transport networks and their changes in the period between 1939 and 2016 focusing on the transformations of urban spatial structure genotypes in the period 1960-1990 and their significance in the context of urban development from 1939 until 2016;

- iconographical data (photographs, postcards, drawings) and other documents regarding the use and the users of public spaces before the boom of modernist transforma- 

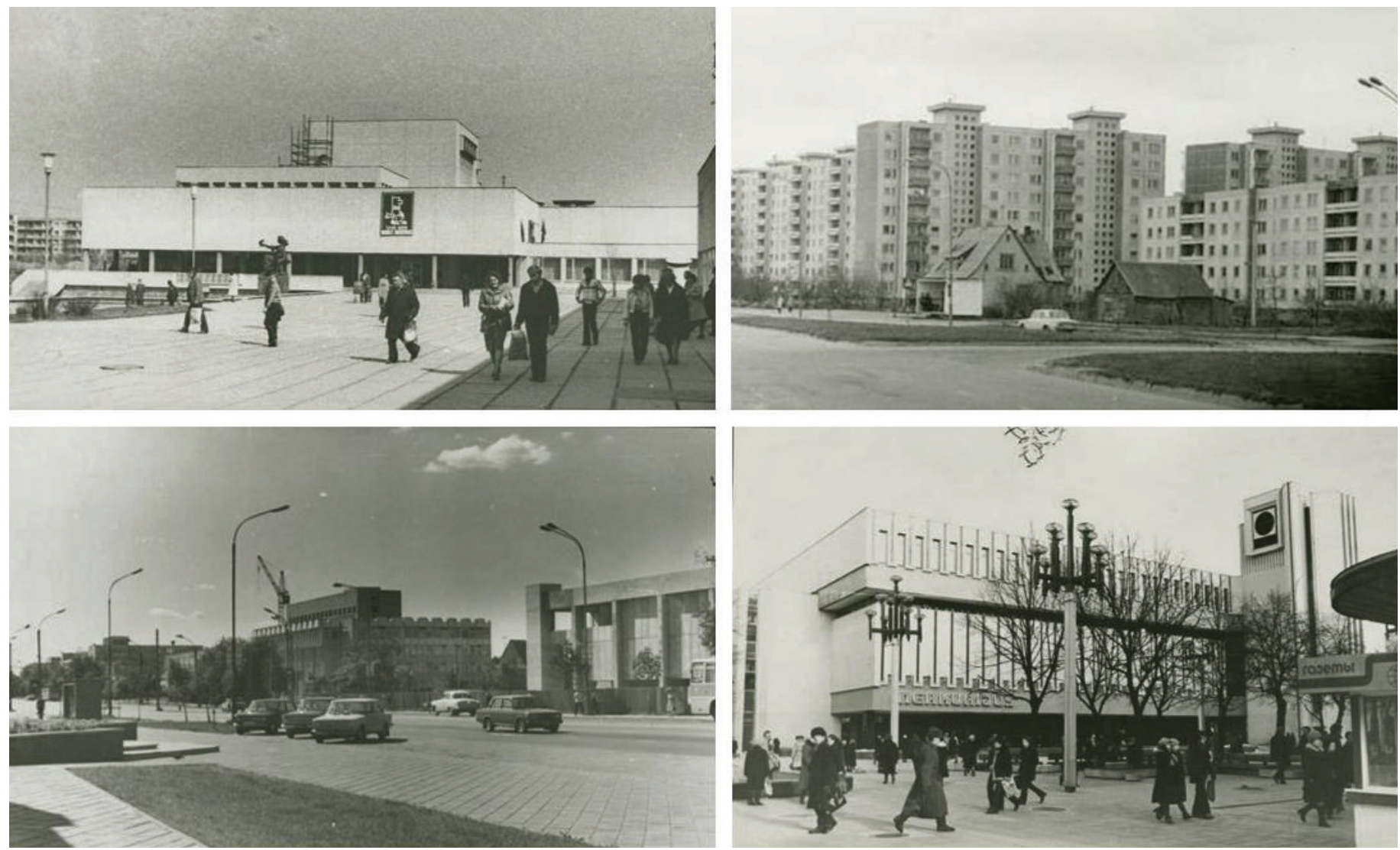

Fig. 1. Historical iconographical material: public spaces developed or reconstructed during the Soviet period in the photographs of 1980 s by photographer A. Pleskačiauskas [18].

tions (inter-war era, period until 1960), in the era of modernization (1960-1990) and after it (Fig. 1);

- $\quad$ sociological data on the memories of residents about use of public spaces in the selected urban areas during the Soviet era and present characteristics and use of these spaces.

\section{Integration of Research Results}

In order to use the above distinguished methods and data effectively for the evaluation of transformations of genotypes of urban structures that had occurred in the period 1960-1990 and their meaning in the context of urban development in 1939-2016, and to determine the genotypic features of spaces that influence social-economic processes taking place in them, several steps and directions of data and methods integration will be necessary.

- GIS will be used as a tool for integration of historical spatial, iconographical and other data in the development of spatial structure of large Lithuanian cities from 1939 until present. In the further stages of research, the developed GIS database will be complemented with the results of content analysis of iconographical material regarding the cultural-social contents of public spaces in 1939-1990;

- $\quad$ sociological data integration will encompass the development of typologies of public spaces, public space users and activities taking place in public spaces that will be applied both in the content analysis of spatial structure functioning phenomena and sociological surveys and observations. The typology of activities or functions will be developed using sociotop map approach [17], which presents a wide array of potential activities, including bathing, play, picnic, boating etc.;

- $\quad$ elaboration of methodology for multi-modal network model development will be carried out using at least two different tools, for example, Depthmap (space syntax), ComplexNetGIS (general graph theory), sDNA (graph theory integrated with space syntax possibilities) etc. This will allow to adapt and to elaborate multi-modal network model for the purposes of this research, which enables the more precise and detailed analysis of fragmentation of urban fabric, determined by the modernist urbanism and the separation of traffic flows inherent to it. In cases, when only space syntax or similar models are applied for the description of the street network, the problems of identification and evaluation of specific features of modernist urban fabric (influence of separation of traffic flows on the functioning of urban spaces, etc.) arise; thus in this research the above-mentioned new urban fabric analysis methodology will be applied. It is based on the idea of multi-modal multi-layer graph that currently exists only 
Architecture and Urban Planning

Kẹstutis Zaleckis, Indrẻ Gražulevičiūtė-Vilenišké, Jurga Vitkuvienė, Brigita Tranavičiūtė, Huriye Armağan Doğan, Tomas Grunskis, Jolita Sinkienẻ Integrated Socio-spatial Analysis of Soviet Era Modernist Urbanization and its Consequences in Lithuanian Cities: Methodological Outline
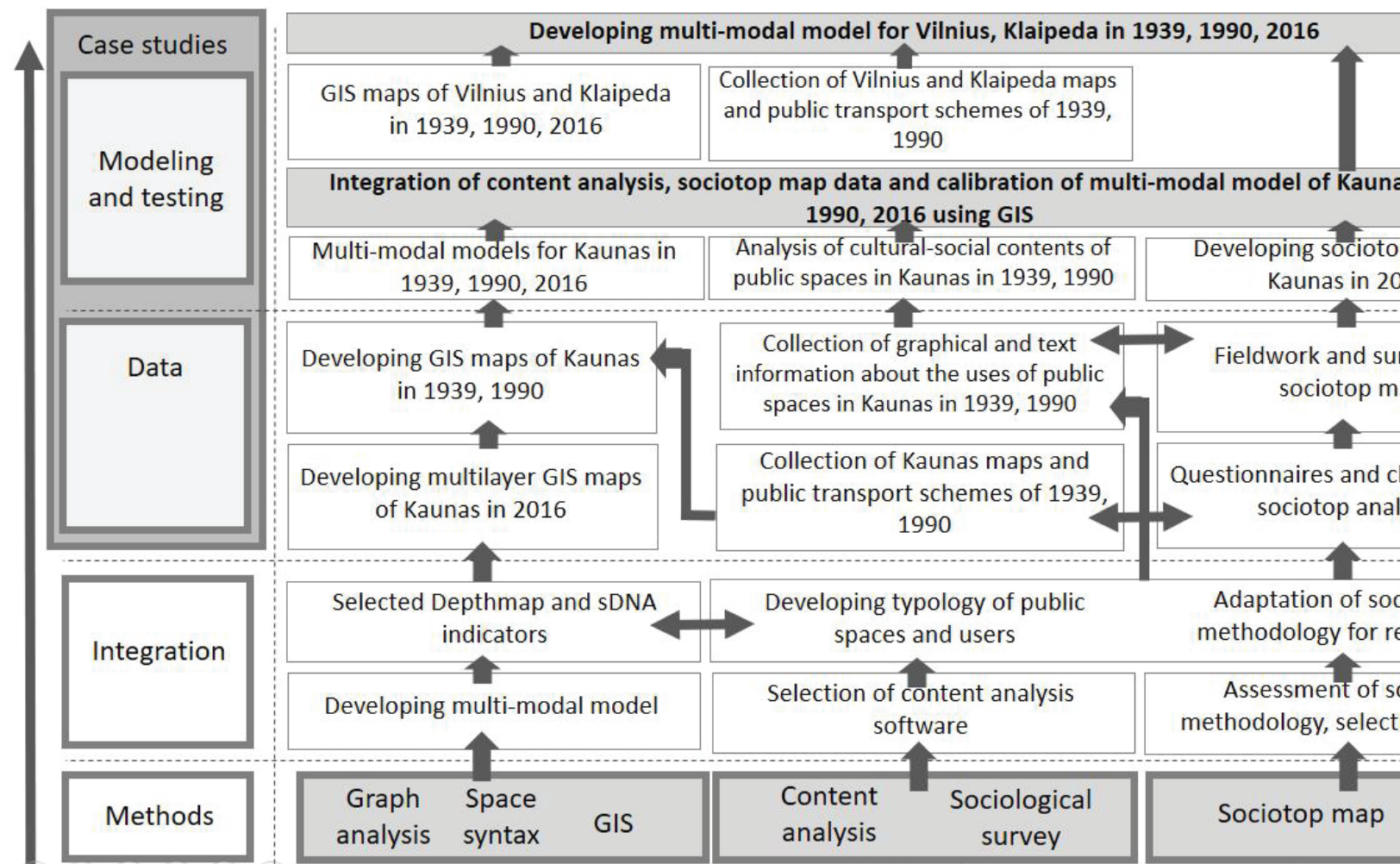

Integration of content analysis, sociotop map data and calibration of multi-modal model of Kaunas in 1939, 1990, 2016 using GIS

\begin{tabular}{|c|c|c|}
\hline $\begin{array}{l}\text { Multi-modal models for Kaunas in } \\
\qquad 1939,1990,2016\end{array}$ & $\begin{array}{l}\text { Analysis of cultural-social contents of } \\
\text { public spaces in Kaunas in } 1939,1990\end{array}$ & $\begin{array}{l}\text { Developing sociotop map for } \\
\text { Kaunas in } 2016\end{array}$ \\
\hline $\begin{array}{l}\text { Developing GIS maps of Kaunas } \\
\text { in } 1939,1990\end{array}$ & $\begin{array}{l}\text { Collection of graphical and text } \\
\text { information about the uses of public } \\
\text { spaces in Kaunas in } 1939,1990\end{array}$ & $\begin{array}{l}\text { Fieldwork and surveys for } \\
\text { sociotop map }\end{array}$ \\
\hline $\begin{array}{l}\text { Developing multilayer GIS maps } \\
\text { of Kaunas in } 2016\end{array}$ & $\begin{array}{c}\text { Collection of Kaunas maps and } \\
\text { public transport schemes of } 1939 \\
1990\end{array}$ & $\begin{array}{l}\text { Questionnaires and checklists for } \\
\text { sociotop analysis }\end{array}$ \\
\hline $\begin{array}{c}\text { Selected Depthmap and sDNA } \\
\text { indicators }\end{array}$ & $\begin{array}{c}\text { Developing typology of public } \\
\text { spaces and users }\end{array}$ & $\begin{array}{l}\text { Adaptation of sociotop } \\
\text { methodology for research }\end{array}$ \\
\hline Developing multi-modal model & $\begin{array}{c}\text { Selection of content analysis } \\
\text { software }\end{array}$ & $\begin{array}{l}\text { Assessment of sociotop } \\
\text { methodology, selection of tools }\end{array}$ \\
\hline $\begin{array}{cc}\text { Graph } & \text { Space } \\
\text { analysis } & \text { syntax }\end{array}$ GIS & $\begin{array}{l}\text { Content } \\
\text { analysis }\end{array}$ & Sociotop map \\
\hline Spatial & Sociological & Socio-spatial \\
\hline
\end{tabular}

Fig. 2. The outline of developed complex research methodology integrating the analysis of structure of urban spaces and their socio-cultural contents [Figure: K. Zaleckis, I. Gražulevičiūtė-Vileniškè, J. Vitkuvienè, B. Tranavičiūte, H. Armağan Doğan, T. Grunskis, J. Sinkienė].

at conceptual level [19], [20] and will allow more precise research of modernist urban structures;

- integration of spatial and sociological data will include overlaying the network model of Kaunas with the historical information on the use of public spaces including the results of content analysis using the methodological and technical possibilities presented by GIS databases. Such overlay will allow identifying of the data gaps, which require additional sociological surveys and observations on site. Sociotop map development for the selected characteristic modernist urban spaces created during the Soviet period will integrate spatial and sociological data as well;

- the final calibration of the multi-modal network model using the case of Kaunas will requires overlay and comparison of the network with GIS database layers: information on the historical functions of public spaces (results of content analysis) and the information of the present day use of modernist urban spaces created during the Soviet period (sociological surveys results and sociotop map).

\section{CONCLUSION}

1. One of the crucial transformations regarding the influence on contemporary urban development in Lithuania was the massive modernist urbanization of the Soviet era; however, neither this transformation, nor its visible and invisible influences on the contemporary urban development are comprehensively analysed and understood. Without research, it is not possible to fully understand the evolution of Lithuanian cities and how and why they are functioning today. This encourages to carry out such analysis and to develop complex research methodology.

2. The presented research methodology is based on the analysis of urban structures as a spatial graph using a multi-modal network model. An attempt to combine the properties of a spatial urban framework with cognitive framework is presented. When developing the methodology, special attention is paid to linking results of content analysis of historical photographs and other material with the specific physical types of urban spaces and sociotops (focusing on the activities of users in the public spaces). It seeks to find out how the formal typology of modernist urban spaces corresponds to the real existing and perceived ones. It is important to note that the proposed methods are more or less tested in urban studies, but the presented combination of models should be seen as the original one.

3. For better application and use as a background for design solutions, the developed methodology will be calibrated using the case of Kaunas; its application to Vilnius and Klaipeda is planned as well. The outline of the methodology development and application is presented in the Fig. 2. 
4. The advantages of the proposed methodology include:

- the methodology combines graph models, content analysis and sociotop map approaches and allows to see the structure of urban spaces and its social meta-content as one continuum;

- this complex combination will create the background for deeper understanding of the regularities of functioning of spatial urban structures with focus on their genotypical features instead of more often analysed phenotypic ones.

\section{AcKnowledgements}

This research was funded by a grant (28 022017 No. S-MOD-17-16/SV3-0364) from the Research Council of Lithuania.

\section{REFERENCES}

1. Miškinis, A. Lietuvos urbanistika : istorija, dabartis, ateitis. Vilnius: Mintis, 1991. $154 \mathrm{p}$

2. Minkevičius, J. Naujoji Lietuvos architektūra. Vilnius: Mintis, 1982 $142 \mathrm{p}$.

3. Drèmaitė, M., Petrulis, V., Tutlytè, J. Architektūra sovietinèje Lietuvoje Vilnius: Vilniaus dailès akademijos leidykla, 2012. 411 p.

4. Tutlytè, J. Rekreacinè architektūra Lietuvos kurortuose (1940-1990) kompleksinis kokybès vertinimas. Kaunas: Vytauto Didžiojo universitetas, 2002. $61 \mathrm{p}$.

5. Drèmaitè, J. The (post-) Soviet built environment : Soviet - western relations in the industrialized mass housing and its reflections in the Soviet Lithuania. Lithuanian Historical Studies, 2011, Vol. 15, pp. 11-27.

6. Grunskis, T., Siupšinskas, M. Tarybinio laikotarpio viešųų erdvių transformacijos Lietuvoje. Vilniaus Žirmūnu ir Lazdynu atvejis. Journal of Architecture and Urbanism, 2012, Vol. 36, Issue 3, pp. 209-221. https:// doi.org/10.3846/20297955.2012.732492

7. Grunskis, T., Mankus, M. The system of urban public spaces in the post-communist sociocultural context. Journal of Architecture and Urbanism, 2013, Vol. 37, Issue 3, pp. 210-217. https://doi.org/10.3846/20297 955.2013 .840074

8. Mozūriūnaitè, S. Urbanistiniu funkcijų mutaciju poveikis miesto istorinè aplinkos kaitai. Kaunas: Lithuanian Academic Libraries Network (LABT), 2013. $186 \mathrm{p}$

9. Mozūriūnaitė, S. Transformation of urban functions and physical factors influencing Lithuanian cities. In: SGEM 2016: 3rd international multidisciplinary scientific conference on social sciences and arts. Book. 4. Arts, performing arts, architecture and design. Volume II. Architecture and design, 2016, pp. 6-9.

10. Zaleckis, K., Matijošaitienė, I. Hidden urban revolution in Kaunas downtown area : 1935-1988-2011. In: the proceedings of The eight international space syntax symposium, Pontificia Universidad Católica de Chile, 2012, pp. 1-16.

11. Zaleckis, K., Matijošaitienè, I. Space syntax analysis of Kaunas : some methodological aspects. Journal of Sustainable Architecture and Civil Engineering, 2013, Vol. 1, Issue 2, pp. 29-34. https://doi.org/10.5755/j01. sace.1.2.2791

12. Zaleckis, K., Matijošaitienè, I., Sinkienè, J. Spatial structure of a city and security of inhabitants : the post-soviet case. In: ICASS 2013: 2013 $3 r d$ international conference on applied social science, Taipei, Taiwan January 15-16, 2013. Vol. 2. Newark: Information Engineering Research Institute, 2013, pp. 420-430.

13. Dunnett, J. Le Corbusier and the city without streets. In: The Modern city revisited [T. Deckker, ed.]. Routledge, 2000. $272 \mathrm{p}$.

14. Fitting, P. Urban planning/utopian dreaming : Le Corbusier's Chandigarh today. Utopian Studies, 2002, pp. 69-93.

15. Hillier, B., Hanson, J., Peponis, J. Syntactic analysis of settlements. Architecture and Behaviour, 1987, Vol. 3, Issue 3, pp. 217-231.

16. Pflieger, G., Rozenblat, C. Introduction. Urban networks and network theory : the city as the connector of multiple networks. Urban Studies, 2010 Vol. 47, Issue 13, pp. 2723-2735. https://doi.org/10.1177/0042098010377368

17. Ståhle, A. Sociotope mapping - exploring public open space and its multiple use values in urban and landscape planning practice. Nordic Journal of Architectural Research, 2006, Vol. 19, Issue 4, pp. 59-71.

18. Collection of Aleksandras Pleskačiauskas manuscripts about Kaunas [online]. E-paveldas [cited 11.07.2017]. http://www.epaveldas.lt/
paieska?p_p_id=searchresultsportlet_WAR_searchresultsportlet10SNAP_ SHOT\&q=aleksandras $\% 20$ pleska $\% \overline{\mathrm{C}} 4 \% 8$ Diauskas $\& \mathrm{t}=1$

19. Gil, J. Integrating public transport networks in the axial model. In: the proceedings of The eight international space syntax symposium, Pontificia Universidad Católica de Chile, 2012, pp. 8103:1-8103:21

20. Gil, J. Analysing the configuration of multi-modal urban networks. Geographical Analysis, 2014, Vol. 46, Issue 4, pp. 368-391. https://doi. org/10.1111/gean.12062

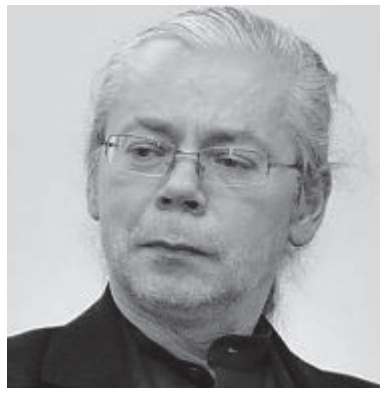

Kestutis Zaleckis (b. Kaunas, 1969) obtained the Diploma in Architecture in 1992 from Vilnius Gediminas Technical University, the degree of Doctor of Humanities in 2002 from Vytautas Magnus University. He is currently a Professor with the Department of Architecture and Urbanism of the Faculty of Civil Engineering and Architecture of Kaunas University of Technology. His research interests are evolution and mutations of urban spatial genotypes, urban history.

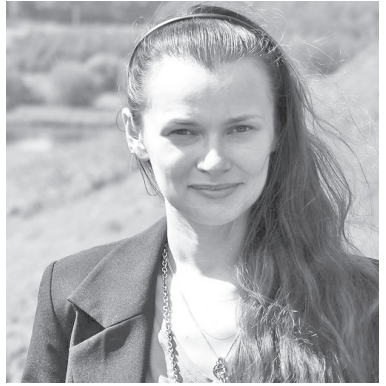

Indrè Gražulevičiūtė-Vileniškẻ (b. Kaunas, 1981) received the degree of Bachelor of Architecture in 2003, the degree of Master of Land Management in 2005 and the degree of Doctor of technological sciences in 2009, from Kaunas University of Technology. From 2009-2012, she was a Lecturer with the Department of Architecture and Land Management of Faculty of Civil Engineering and Architecture of Kaunas University of Technology. Since 2012, she has been and Associated Professor with the Department of Architecture and Urbanism of the Faculty of Civil Engineering and Architecture of Kaunas University of Technology. Her research interests are valuation and preservation of cultural heritage, management of rural-urban interface, sustainable architecture.

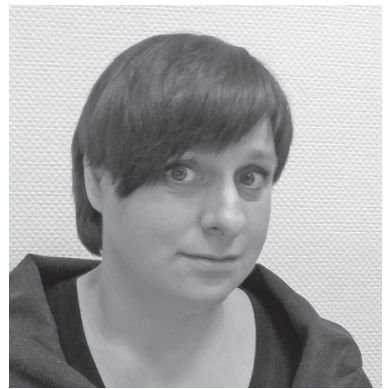

Jurga Vitkuvienè (b. Kaunas, 1976) received the degree of Bachelor of Architecture in 1998 and the degree of Master of Architecture in 2000. Since 2005, she has been a Lecturer with the Department of Architecture and Urbanism of Faculty of Civil Engineering and Architecture of Kaunas University of Technology. Her research interests are urban history, management of rural-urban interface, urban ecology, sustainable landscape and architecture.

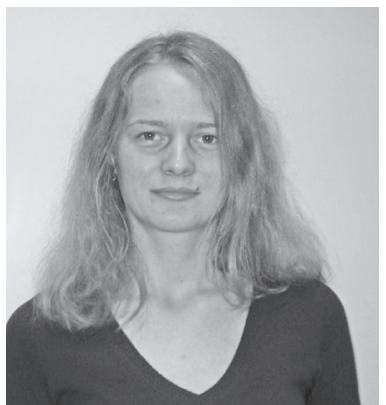

Brigita Tranavičiūtè (b. Kaunas, 1985) received the degree of Bachelor of History in 2007, the degree of Master of Law in 2010, and the degree of Doctor of Humanities in 2015 from Vytautas Magnus University. Since 2016, she has been a Junior Researcher with the Institute of Architecture and Construction of Kaunas University of Technology.

Current and previous research interests: Soviet architecture and urbanism, Soviet economics and trade, post-Soviet economics and trade. 


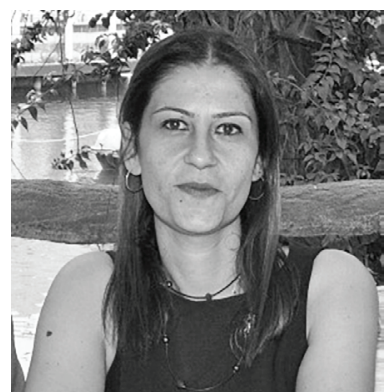

Huriye Armağan Doğan (b. Turkey, 1983) received the degree of Bachelor of Architecture in 2008 and the degree of Master of Restoration and Conservation of Cultural Heritage in 2011. She is currently a $\mathrm{PhD}$ Student with the Institute of Architecture and Construction of Kaunas University of Technology.

Her research interests are adaptive re-use, preservation of cultural heritage, modern movement, early 20 th century architecture, cultural memory.

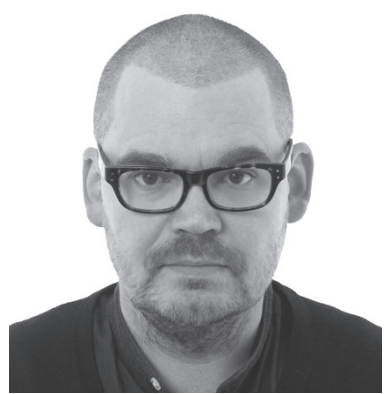

Tomas Grunskis (Kaunas, 1972). Bachelor of Architecture, 1994, Master of Architecture, 1996, Vilnius Gediminas Technical University. Associated professor at Vilnius Academy of Arts, Department of Architecture.

Current and previous research interests: urban compositions, urban morphology and anthropology, contemporary experimental architecture

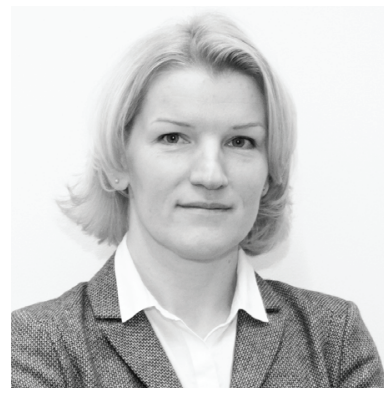

Jolita Sinkienė (Kaunas, 1974). Associated professor at Kaunas University of Technology, Faculty of Social Sciences, Humanities and Arts, Institute of Public Policy and Administration and Senior Researcher at Kaunas University of Technology, Faculty of Civil Engineering and Architecture, Department of Architecture and Urbanism. Current and previous research interests: urban development policy, urban governance, strategic urban management, vitality of urban communities.

\section{Contact Data}

Kęstutis Zaleckis

Kaunas University of Technology, Faculty of Civil Engineering and Architecture, Department of Architecture and Urbanism

Address: 48 Studentu St., Kaunas, 51367, Lithuania

Tel.: +370 37451546

E-mail: kestutis.zaleckis@ktu.lt

\section{Indrẻ Gražulevičiūtė-Vileniškè}

Kaunas University of Technology, Faculty of Civil Engineering and Architecture, Department of Architecture and Urbanism

Address: 48 Studentu St., Kaunas, 51367, Lithuania

Tel.: +370 37451546

E-mail: indre.grazuleviciute@ktu.lt

\section{Jurga Vitkuvienè}

Kaunas University of Technology, Faculty of Civil Engineering and Architecture, Department of Architecture and Urbanism

Address: 48 Studentu St., Kaunas, 51367, Lithuania

Tel.: +370 37451546

E-mail: jurga.vitkuviene@ktu.lt

\section{Brigita Tranavičiūtè}

Kaunas University of Technology, Institute of Architecture and Construction

Address: 60 Tunelio St., Kaunas, 44405, Lithuania

E-mail: brigita.tranaviciute@ktu.lt

\section{Huriye Armağan Doğan}

Kaunas University of Technology, Institute of Architecture and Construction

Address: 60 Tunelio St., Kaunas, 44405, Lithuania

Tel.: +370 61670650

E-mail: huriye.dogan@ktu.edu

\section{Tomas Grunskis}

Vilnius Academy of Arts, Department of Architecture

Address: 5 Malūnu St., Vilnius, 01200, Lithuania

E-mail: grunskis@gmail.com

\section{Jolita Sinkiené}

Kaunas University of Technology, Faculty of Social Sciences, Arts and Humanities

Address: 37 A. Mickevičiaus St., Kaunas, 44244, Lithuania

E-mail: jolita.sinkiene@ktu.lt 